\title{
Interactive comment on "Argon offline-AMS source apportionment of organic aerosol over yearly cycles for an urban, rural and marine site in Northern Europe" by C. Bozzetti et al.
}

Anonymous Referee \#2

Received and published: 30 June 2016

Please see attached.

Please also note the supplement to this comment:

http://www.atmos-chem-phys-discuss.net/acp-2016-413/acp-2016-413-RC2-

supplement.pdf 